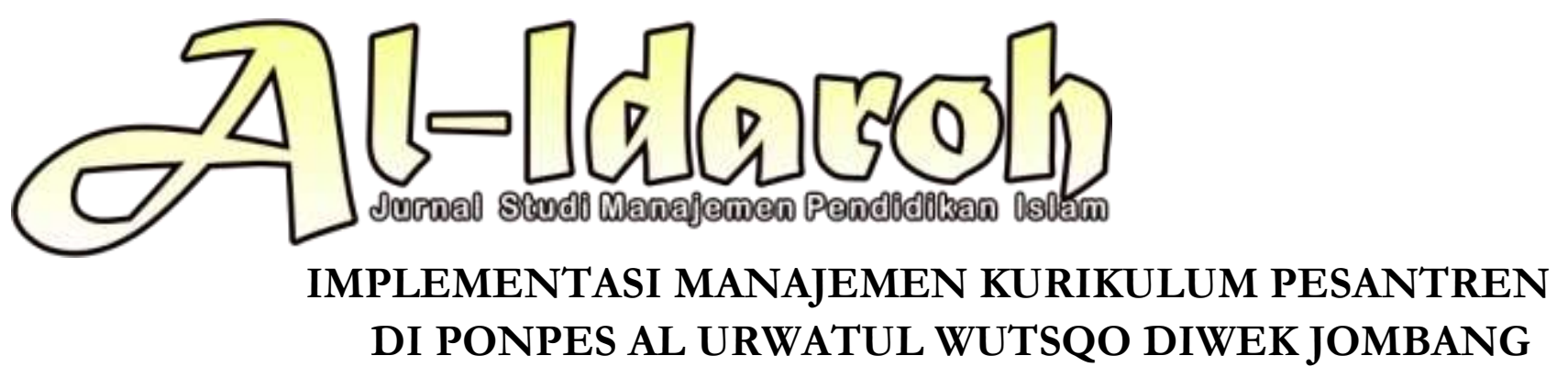

\author{
Nurul Indana \\ Prodi Pendidikan Agama Islam STIT Al Urwatul Wutsqo Jombang \\ Email: nurulidana91@gmail.com \\ Lenny Nurvita \\ Prodi Pendidikan Agama Islam STIT Al Urwatul Wutsqo Jombang \\ Email: lenny.nurvita@yahoo.com
}

\begin{abstract}
Islamic boarding schools are traditional Islamic educational institutions to study, understand, explore, live, and practice Islamic teachings by emphasizing the importance of religious morals as guidelines for daily behavior. Curriculum management is important, to make the mission and vision of the boarding school targets in accordance with the boarding school objectives based on the level and necessary. Curriculum management includes planning, implementing, and evaluating curriculum activities. The curriculum management of Al Urwatul Wutsqo Islamic boarding school, is al Qur'an-based (Qur'an and Interpretation Development). This study is a qualitative research method, with data collection using interviews, observation and documentation and triangulation as an anlysis. The results of the study are conducting deliberations and coaching with the boarding school caretakers and all religious teachers / clerics (planning), the implementation is the activity of qur'any learning and tafsir amaly, and in evaluation is the responsible report to ustadz/ustadzah about the results, supporting factors: the curriculum has made can be followed since all teachers are the alumni of the Islamic boarding school Al Urwatul Wutsqo, and the inbibiting factor is the bussines of the teacher ho are studying, so that their time is disturbed.
\end{abstract}

Keywords: Curriculum, Management

\title{
Pendahuluan
}

Pesantren adalah lembaga pendidikan tradisional Islam untuk mempelajari, memahami, mendalami, menghayati, dan mengamalkan ajaran Islam dengan menekankan pentingnya moral keagamaan sebagai pedoman perilaku sehari-hari ${ }^{1}$. Kata "tradisional" dalam batasan ini tidaklah merujuk dalam arti tetap tanpa mengalami penyesuaian, tetapi merujuk bahwa lembaga ini hidup sejak ratusan tahun (300-400 tahun) yang lalu dan telah menjadi bagian yang mendalam dari sistem kehidupan sebagian besar umat Islam Indonesia, yang merupakan golongan

${ }^{1}$ Rofiq.Pemberdayaan Pesantren. (Yogyakarta: Pustaka Pesantren, 2005), 1. 
mayoritas, dan telah mengalami perubahan dari masa ke masa sesuai dengan perjalanan hidup umat.

Pengertian pondok pesantren terdapat berbagai variasi, antara lain; Secara etimologis, pondok pesantren adalah gabungan dari pondok dan pesantren. Pondok, berasal dari bahasa Arab funduk yang berarti hotel, yang dalam pesantren Indonesia lebih disamakan dengan lingkungan padepokan yang dipetak-petak dalam bentuk kamar sebagai asrama bagi para santri. ${ }^{2}$

Masa sebelum Indonesia merdeka pesantren telah berperan besar dalam melahirkan pejuang-pejuang yang tangguh dalam memperjuangkan kemerdekaan. Setelah kemerdekaan pesantren juga terus berperan dalam mencerdaskan anak bangsa, hal ini sangat senada dengan tujuan pendidikan nasional sendiri, yaitu mencerdaskan kehidupan bangsa, sedangkan pesantren di era globalisasi walaupun sudah mendapat legitimasi dari pemerintah, namun ada juga pandangan dari kalangan masyarakat bahwa lulusan pesantren hanya bisa shalat dan mengaji. ${ }^{3}$

Pesantren sebagai lembaga pendidikan Islam yang tertua di Indonesia, pesantren memiliki akar sejarah yang jelas. Menurut para ahli sejarah orang yang pertama kali mendirikan pesantren terdapat perselisihan pendapat, sehingga mereka menyebutkan Syaikh Maulana Malik Ibrahim, yang dikenal dengan Syaikh Maghribi, dari Gujarat, India, sebagai pendiri pesantren yang pertama kali di Jawa. Lembaga pendidikan ini selalu mencari lokasi untuk menyalur dakwah tersebut tepat sasaran sehingga terjadi benturan nilai-nilai yang dibawanya dengan nilai-nilai yang telah mengakar di masyarakat setempat. ${ }^{4}$

Pengembangan yang mendesak untukdilakukan di pesantren adalah pembaharuan yang bersifat horizontal, pembaharuan ini meliputi sistem pendidikan dan manajemen pesantren, pembaharuan sistem pendidikan ini meliputi: jenis, jenjang, dan sumber daya pendidikan. Pembaharuan jenis pendidikan adalah dengan memasukkan jenis pendidikan lain disamping pendidikan agama seperti pendidikan akademik atau pendidikan kejuruan (keterampilan). Jenis pendidikan akademik

\footnotetext{
${ }^{2}$ Ridlwan Nasir,Mencari Tipologi Format Pendidikan Ideal, Pondok Pesantren di Tengah Arus Perubahan.(Yogyakarta: Pustaka pelajar, 2005), 60.

${ }^{3}$ Mujamil Qomar, Pesantren dari Transformasi Metodologi Menuju Demokratisasi Institusi,(Jakarta: Glora Aksara Pertama, 2015), 90.

${ }^{4}$ M. Rohinah. Memodernisasi NU 7\& Pendidikan Islam, Jakarta: Grafindo Khasanah Ilmu,2012),8.
} 


\section{Implementasi Manajemen Kurikulum Pesantren di Pon Pes Al Urwatul Wutsqo Diwek Jombang}

dimaksud untuk mengantisipasi pesatnya perkembangan ilmu pengetahuan di luar dunia pesantren, sehingga di perlukan sebuah pendekatan yang bersifat religiusdokteriner dalam menyampaikan misi pesantren, sedangkan pembaharuan pendidikan kejuruan adalah untuk menciptakan relevansi antara dunia pendidikan pesantren dengan kebutuhan masyarakat. ${ }^{5}$

Ada tiga faktor dalam sistem manajemen pendidikan nasional, yaitu manajemen sebagai faktor upaya, organisasi sebagai faktor sarana, dan administrasi sebagai faktor karsa. Tiga kategori ini dapat diberikan arah dan perpaduan dalam merumuskan, mengendalikan pelaksanaan, mengawasi serta menilai pelaksanaan kebijakankebijakan dalam upaya mencapai suatu tujuan, kebutuhan pesantren akan kebutuhan manajemen yang mendukung dapat dikatakan cukup mendesak terutama bagi pesantren yang besar dan memiliki jenis pendidikan yang beragam dengan jumlah santri yang besar pula. Untuk kategori ini perlu dipandang perlunya manajer yang handal dan sangat mungkin satu saat kiai bertindak bertindak sebagai manajer.

Kurikulum merupakan alat yang penting dalam keberhasilan suatu pendidikan, tanpa kurikulum yang baik dan tepat maka akan sulit dalam mencapai tujuan dan sasaran pendidikan yang telah di cita-cita oleh suatu lembaga pendidikan, karena segala hal harus ada manajemennya bila ingin menghasilkan sesuatu yang baik, sesuai dengan apa yang diharapkan, maka hal yang menjadi tolak ukur paling berpengaruh diantaranya adalah kurikulum yang dikelola dengan baik, dimana kurikulum senantiasa mengalami perubahan sesuai dengan perkembangan zaman.

Kurikulum pendidikan di Indonesia telah mengalami pergantian hampir setiap sepuluh tahun sekali, meskipun di akhir-akhir tahun belakangan terjadi beberapa pergantian yang menimbulkan dampak positif maupun negatif. Kurikulum pendidikan yang bisa dilaksanakan sesuai dengan perencanaan yang matang dengan penuh kreativitas dan inovasi pembelajaran akan berhasil dengan baik daripada yang hanya sebagai formalitas saja. Sudah menjadi fenomena umum bahwa dalam kenyataan di lapangan suatu lembaga pendidikan tampak sukses jika bisa merencanakan program-program pendidikan dan mampu melaksanakan dengan baik

${ }^{5}$ Hamid Hasan, Evaluasi Kurikulum, (Bandung: Remaja Rosdakarya. 2009), 104. 
sesuai dengan tuntutan zaman. Sesuai dengan firmannya dalam Surat Ar Ra'd Ayat 11:

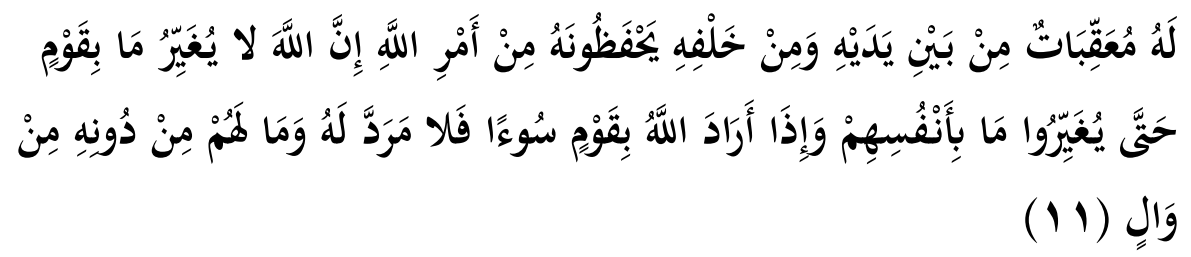

Artinya: "Bagi manusia ada malaikat-malaikat yang selalu mengikutinya bergiliran, di muka dan di belakangnya, mereka menjaganya atas perintah Allah. Sesungguhnya Allah tidak merubah keadaan sesuatu kaum sehingga mereka merubah keadaan yang ada pada diri mereka sendiri. Dan apabila Allah menghendaki keburukan terhadap sesuatu kaum, maka tak ada yang dapat menolaknya; dan sekali-kali tak ada pelindung bagi mereka selain Dia.

Berkaitan dengan pesantren sebagai lembaga pendidikan konsep kurikulum yang digunakan dalam pesantren tidak hanya mengacu kepada pengertian kurikulum sebagai materi semata-mata, melainkan jauh lebih luas dari itu, yakni menyangkut keseluruhan pengalaman belajar santri yang masih berada alam tanggung jawabnya pesantren, sehingga misi dan cita-cita pesantren dapat berperan dalam pembangunan masyarakat.

Berdasarkan hasil pengamatan peneliti di Pondok Pesantren al Urwatul Wutsqo kurikulum yang digunakan di pondok pesantren al Urwatul Wutsqo Diwek Jombang adalah kurikulum qur'any dan pengembangan tafsir amaly (al Qur'an to be practiced) yang merupakan ciri khas pondok tersebut,tentunya hal ini akan banyak mata pelajaran yang diambil oleh santri sehingga manajemen kurikulum harus dipersiapkan secara tepat dn memberikan kenyamanan dalam belajar para santri, sehingg lulusannya dapat melanjutkan ke jenjang pendidikan yang lebih tinggi, baik di dalam maupun diluar negeri.

Manajemen kurikulum dengan sistem qur'any dan pengembangan tafsir amaly harus bisa merubah cara pandang masyarakat yang keliru, hal ini juga harus didukung dengan prestasi yang dikuasai para santri, sehingga pandangan masyarakat terhadap pendidikan yang diterapkan di pondok pesantren pada akhirnya bisa memberi kontribusi besar kepada masyarakat.

Gambaran diatas tentunya tidak terlepas dengan peran seorang stakeholder, ustadz/ustadzah, dan santri atau tim penyusun kurikulum pesantren dalam 


\section{Implementasi Manajemen Kurikulum Pesantren di Pon Pes Al Urwatul Wutsqo Diwek Jombang}

manajemen kurikulum yang sangat berpengaruh bagi kemajuan lembaganya serta mempunyai kebijakan strategis untuk mendukung program tersebut,sehingga dalam hal tersebut dapat mengubah pendidikan karakter santri dalam berakhlak mulia. Hal yang perlu dipertimbangkan atau menjadi tolak ukur dalam menyusun kurikulum diantaranya adalah:stakeholder, ustadz/ustadzah, santri, sarana prasarana, dan tenaga kependidikan.

Kurikulum qur'any dan pengembangan tafsir amaly pasti akan mempengaruhi proses pembelajaran yang berlangsung selama 24 (dua puluh empat) jam baik kegiatan intrakurikuler, kointrakurikuler, dan ekstrakurikuler. diantara program intrakurikuler adalah qur'any, pengembangan tafsir amaly, imtaqisasi mata pelajaran. Diantara program kointrakurikukuler adalah amal shalih seperti amal shalih di dapur, bangunan, administrasi, asisten guru, istighasah, zikir, salat berjama'ah, salat tahajjud, puasa sunnah, dan lain-lain di maksudkan untuk menbentuk sikap cinta kepada Allah SWT. Diantara program ekstrakurikuler adalah seperti program seni qasidah al Banjari (Qasidah Ilmu) agar terbentuk karakter murid, dan dapat memengaruhi pola pikir, cara pandang, serta menarik murid, Qasidah Ilmu tidak hanya dilantunkan pada hari atau momen tertentu, akan tetapi setiap pengajian. Kandungan Qasidab Ilmu mengandung banyak nilai kebaikan, seperti nilai keimanan kepada Allah SWT, akhirat, surga, dan neraka.

Berdasarkan fakta dan teori yang dipaparkan diatas tentang manajemen kurikulum pesantren yang telah diterapkan di salah satu lembaga di Pondok Pesantren al Urwatul Wutsqo Diwek Jombang. Oleh karena itu, peneliti ingin mengetahui implementasi terhadap manajemen kurikulum pesantren.

Berangkat dari deskripsi tersebut, maka peneliti tertarik untuk mengadakan penelitian dengan judul Implementasi Manajemen Kurikulum Pesantren di Pondok Pesantren al Urwatul Wutsqo Diwek Jombang.Penelitian ini berfokus pada Implementasi Manajemen Kurikulum yang digunakan di Pondok Pesantren al Urwatul Wutsqo Diwek Jombang yang mencakup tahap perencanaan, tahap pelaksanaan, dan tahap evaluasi. 


\section{Pembahasan}

\section{A. Manajemen Kurikulum}

1. Pengertian Manajemen Kurikulum

Manajemen kurikulum adalah sebagai suatu sistem pengelolaan kurikulum yang kooperatif, komprehensif, sistemik, dan sistematis dalam rangka mewujudkan ketercapaian tujuan kurikulum ${ }^{6}$

Manajemen kurikulum mencakup kegiatan perencanaan, pelaksanaan, dan evaluasi kurikulum ${ }^{7}$. Dalam manajemen kurikulum kegiatan dititikberatkan pada usaha-usaha pembinaan situasi belajar di sekolah agar selalu terjamin kelancarannya. Kegiatan manajemen kurikulum diantaranya sebagai berikut:

a.Perencanaan kurikulum

Perencanaan kurikulum adalah sebagai suatu proses sosial yang kompleks, yang menuntut berbagai jenis dan tingkat perbuatan keputusan dengan mempertimbangkan kebutuhan masyarakat melalui model perencanaan yang tepat. Guru yang baik akan berusaha sedapat mungkin agar pengajarannya berhasil ${ }^{8}$, Salah satu faktor yang dapat membawa keberhasilan itu, adalah adanya perencanaan pengajaran yang dibuat guru tersebut sebelumnya.

Sebagaimana firman Allah SWT dalam al-Qur'an surat al-Hasyr (59) ayat 18:

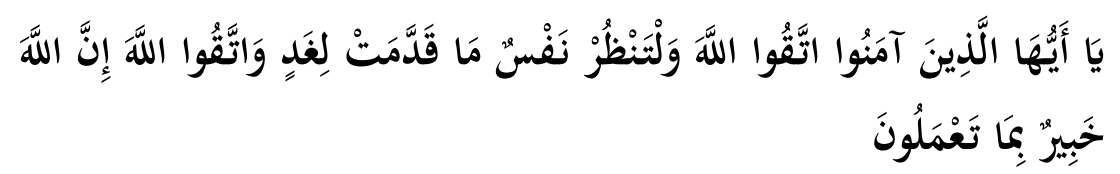

Artinya: "Hai orang-orang yang beriman, bertakwalah kepada Allah dan hendaklah Setiap diri memperhatikan apa yang telah diperbuatnya untuk hari esok (akhirat); dan bertakwalah kepada Allah, Sesungguhnya Allah Maha mengetahui apa yang kamu kerjakan”.

b. Pelaksanaan kurikulum

Penerapan atau pelaksanaan program kurikulum yang telah dikembangkan dalam tahap sebelumnya, kemudian diujicobakan dengan pelaksanaan dan pengelolaan, sambil senantiasa dilakukan penyesuaian

\footnotetext{
${ }^{6}$ Sholeh. Hidayat, Pengembangan Kurikulum, (Bandung: Rosdakarya. 2013), 86.

${ }^{7}$ OemarHamalik.Dasar-dasar Pengembangan Kurikulum, (Bandung: Remaja Rosdakarya.2007), 204.

${ }^{8}$ Dakir. Perencanaan dan Pengembangan Kurikulum, (Yogyakarta: Rineka Cipta, 2004),3.
} 


\section{Implementasi Manajemen Kurikulum Pesantren di Pon Pes Al Urwatul Wutsqo Diwek Jombang}

terhadap situasi lapangan dan karakteristik peserta didik, baik pengembangan intelektual, emosional, serta fisiknya.

Sebagaimana firman Allah SWT dalam al-Qur'an surat al Kahfi (18) ayat 2:

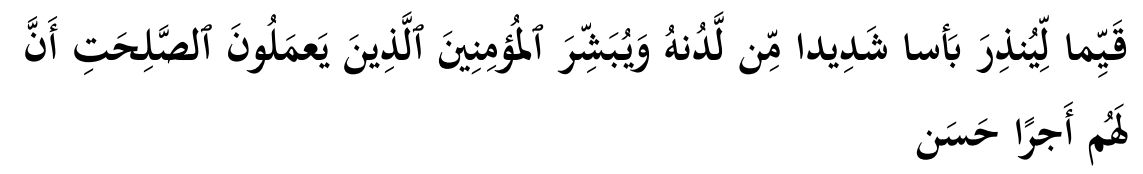

Artinya: "sebagai bimbingan yang lurus, untuk memperingatkan siksaan yang sangat pedih dari sisi Allah dan memberi berita gembira kepada orang-orang yang beriman, yang mengerjakan amal saleh, bahwa mereka akan mendapat pembalasan yang baik."

c.Evaluasi kurikulum

Evaluasi kurikulum suatu proses pengumpulan data secara sistematis, yang bertujuan untuk membantu pendidik memahami dan menilai kurikulum, serta memperbaiki metode pendidikan. Sebagaimana firman Allah SWT dalam al-Qur'an surat al Infithar (82) ayat 10-12:

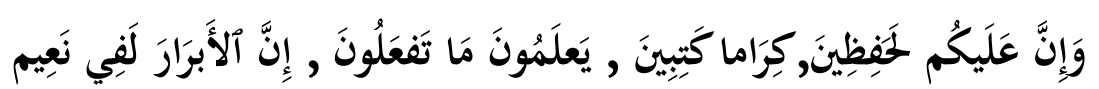

Artinya: "Padahal sesungguhnya bagi kamu ada (malaikat-malaikat) yang mengawasi (pekerjaanmu), yang mulia (di sisi Allah) dan mencatat (pekerjaan-pekerjaanmu itu), mereka mengetahui apa yang kamu kerjakan, Sesungguhnya orang-orang yang banyak berbakti benar-benar berada dalam surga yang penuh kenikmatan."

Terdapat lima prinsip yang harus diperhatikan dalam melaksanakan manajemen kurikulum, ${ }^{9}$ yaitu:

1) Produktivitas, hasil yang akan diperoleh dalam kegiatan kurikulum merupakan merupakan aspek yang harus dipertimbangkan dalam manajemen.

2) Demokratisasi, pelaksanaan manajemen kurikulum harus beraraskan demokrasi yang menempatkan pengelola, pelaksana, dan subjek didik pada posisi yang seharusnya dalam melaksanakan tugas dengan penuh tanggung jawab untuk mencapai tujuan kurikulum.

3) Kooperatif, untuk memperoleh hasil yang diharapkan dalam kegiatan manajemen kurikulum perlu adanya kerja sama yang positif dari berbahagia pihak yang terlibat.

${ }^{9}$ Dinn Wahyudin,Manajemen Kurikulum. (Bandung: Remaja Rosdakarya.2014), 20-21 
4) Efektifitas dan efisiensi, rangakaian manajemen harus mempertimbangkan efektifitas dan efisiensi untuk mencapai tujuan kurikulum sehingga kegiatan manajemen kurikulum tersebut memberikan hasil yang berguna dengan biaya, tenaga, dan waktu yang relative singkat.

5) Mengarahkan visi, misi, dan tujuan yang ditetapkan dalam kurikulum, proses manajemen kurikulum harus dapat memperkuat dan mengarahkan visi, misi dan tujuan kurikulum. ${ }^{10}$

Proses pendidikan perlu dilaksanakan manajemen kurikulum agar perencanaan, pelaksanaan dan evaluasi kurikulum berjalan efektif, efisien, dan optimal dalam memberdayakan berbagai sumber belajar, pengalaman belajar, maupun komponen kurikulum. Menurut Sudarsyah \& Diding ${ }^{11}$ beberapa fungsi dari manajemen kurikulum diantaranya sebagai berikut:

1) Meningkatkan efisiensi pemanfaatan sumber daya kurikulum.

2) Meningkatkan keadilan dan kesempatan kepada siswa untuk mencapai hasil yang maksimal, kemampuan yang maksimal dapat dicapai oleh peserta didik tidak hanya melalui kegiatan intrakurikuler, tapi juga ekstrakurikuler dan kokurikuler yang dikelola secara integritas dalam mencapai tujuan kurikulum.

3) Meningkatkan relevansi dan efektivitas pembelajaran sesuai dengan kebutuhan peserta didik maupun lingkungan sekitar peserta didik, kurikulum yang dikelola secara efektif dapat memberikan kesempatan dan hasil yang relevan dengan kebutuhan peserta didik maupun lingkungan sekitar.

4) Meningkatkan efektivitas kinerja guru maupun aktivitas siswa dalam mencapai tujuan pembelajaran, Meningkatkan efektivitas kinerja guru maupun aktivitas siswa dalam mencapai tujuan pembelajaran.

5) Meningkatkan efektivitas dan efisiensi proses belajar mengajar. Proses pembelajaran selalu dipantau dalam rangka melihat konsisten antara

\footnotetext{
${ }^{10}$ Didin Kurniadin, Manajemen Pendidikan Konsep dan Pengelolaan Pendidikan, (Yogyakarta: Arruz-media. 2014), 241.

${ }^{11}$ Sudarsyah, Asep dan Nurdin Diding, Manajemen Implementasi Kurikulum dalam Tim Dosen Administrasi Pendidikan, Manajemen Pendidikan, (Bandung: Alfabeta. 2009), 192-193
} 


\section{Implementasi Manajemen Kurikulum Pesantren di Pon Pes Al Urwatul Wutsqo Diwek Jombang}

desain yang telah direncanakan dengan pelaksanaan pembelajaran. Dengan demikian ketidaksesuaian antara desain dengan implementasi dapat dihindarkan.

6) Meningkatkan partisipasi masyarakat untuk membantu mengembangkan kurikulum, kurikulum yang dikelola secara professional akan melibatkan masyarakat, khusunya dalam mengisi bahan ajar atau sumber belajar perlu disesuaikan dengan ciri khas kebutuhan pembangunan daerah setempat.

Keberhasilan manajemen kurikulum sangat dipengaruhi oleh faktor manusianya, mulai dari tingkat top leader (ditingkat pusat) sampai dengan tingkat pelaksana dilapangan (guru). Tentu dalam pelaksanaannya, orang tersebut harus didukung oleh sumber-sumber lain, seperti sarana dan prasarana, biaya, waktu, teknologi, termasuk kemampuan manajerialnya ${ }^{12}$. Berdasarkan definisi di atas, maka dapat disimpulkan bahwa manajemen kurikulum adalah suatu kegiatan yang dirancang untuk memudahkan mengelola pendidikan dalam pelaksanaan kegiatan belajar mengajar yang di awali dari tahap perencenaan dan diakhiri dengan evaluasi program, agar kegiatan belajar mengajar dapat terarah dengan baik.

2. Ruang Lingkup Manajemen Kurikulum

Lingkup manajemen kurikulum meliputi perencanaan, pengorganisasian, pelaksanaan, dan evaluasi kurikulum. Pada satuan pendidikan kegiatan kurikulum mengutamakan untuk merealisasikan dan merelevansikan antara kurikulum nasional (SK dan KD) dengan kebutuhan daerah dan kondisi sekolahyang bersangkutan sehingga kurikulum tersebut merupakan kurikulum yang integritas dengan peserta didik maupun dengan lingkungan dimana sekolah itu berada. ${ }^{13}$

Pokok kegiatan utama studi manajemen kurikulum adalah meliputi bidang perencanaan, pengembangan, pelaksanaan, dan perbaikan kurikulum. Manajemen perencanaan dan pengembangan kurikulum berdasarkan asumsi

\footnotetext{
${ }^{12}$ M. Tatang Amirin, Manajemen Pendidikan,(Yogyakarta: UNY Press, 2011), 23-26

${ }^{13}$ OemarHamalik.Dasar-dasar Pengembangan Kurikulum, (Bandung: Remaja Rosdakarya.2007), 15.
} 
bahwa: telah tersedia informasi dan data tentang masalah-masalah dan kebutuhan yang mendasari disusunnya perencanaan yang tepat. Manajemen pengorganisasian meliputi langkah-langkah: perumusan rasional atau dasar pemikiran, perumusan visi misi dan tujuan, penentuan struktur dan isi program pemilihan dan pengorganisasian materi ${ }^{14}$. Manajemen pelaksanaan kurikulum berdasarkan asumsi bahwa kurikulum telah direncanakan sebelumnya dan siap dioperasionalkan. Manajemen perbaikan kurikulum berdasarkan asumsi bahwa, perbaikan kurikulum di sekolah perlu diperbaiki dan dikembangkan lebih lanjut untuk meningkatkan mutu pendidikan. Evaluasi kurikulum berdasarkan asumsi bahwa perbaikan, perencanaan, pengembangan, pelaksanaan, pengadministrasian, evaluasi dan perbaikan kurikulum bergerak dalam satuan sistem dalam siklus yang berkesinambungan dalam lingkaran proses sistem pendidikan menyeluruh. ${ }^{15}$

3. Pengembangan Manajemen Kurikulum

Pengembangan kurikulum adalah proses perencanaan kurikulum agar menghasilkan rencana kurikulum yang luas dan spesifik. Proses ini berhubungan dengan seleksi dan organisasian berbagai komponen situasi belajar-mengajar. ${ }^{16}$

Berikut ini adalah beberapa karakteristik dalam pengembangan kurikulum:

a.Rencana kurikulum harus dikembangakan dengan tujuan yang jelas.

b. Suatu program atau kegiatan yang dilaksanakan di selaras dengan prosedur pengembangan kurikulum.

c.Rencana kurikulum yang baik dapat menghasilkan terjadinya proses belajar yang baik.

d. Rencana kurikulum harus harus mengenalkan dan mendorong diversitas diantara para pelajar.

e.Rencana kurikulum harus menyiapkan semua aspek situasi belajar-mengajar.

\footnotetext{
${ }^{14}$ Dinn Wahyudin,Manajemen Kurikulum. (Bandung: Remaja Rosdakarya.2014),20

${ }^{15}$ OemarHamalik.Dasar-dasar Pengembangan Kurikulum, (Bandung: Remaja Rosdakarya.2007), 20.

${ }^{16}$ OemarHamalik.Dasar-dasar Pengembangan Kurikulum, (Bandung: Remaja Rosdakarya.2007), 183.
} 


\section{Implementasi Manajemen Kurikulum Pesantren di Pon Pes Al Urwatul Wutsqo Diwek Jombang}

f.Rencana kurikulum harus dikembangkan sesuai dengan karakteristik siswa pengguna.

g. The subject arm aproach adalah pendekatan kurikulum yang banyak digunakan disekolah.

\section{B. Pondok Pesantren}

1. Pengertian Pondok Pesantren

Pondok Pesantren adalah lembaga pendidikan yang unik, tidak saja karena keberadaannya yang sangat sudah lama, tetapi juga karena kultur, metode, dan jaringan yang diterapkan oleh lembaga agama tersebut ${ }^{17}$. Sedangkan dari pendapat para ilmuan, pengertian pondok pesantren antara lain:

a.Nurcholish Madjid menegaskan bahwa pondok pesantren adalah artefak peradaban Indonesia yang dibangun sebagai institusi pendidikan keagamaan bercorak tradisional, unik, dan indigenous (asli) ${ }^{18}$.

b. Zamakhsyari Dhofier, bahwa pesantren berasal dari kata santri dengan awalan "pe"di depan dan akhiran "an" yang berarti tempat tinggal para santri. $^{19}$

2. Tujuan Pendidikan Pondok Pesantren

Pesantren sebagai sebuah lembaga pendidikan mempunyai tujuan yang dirumuskan dengan jelas sebagai acuan progam-progam pendidikan yang diselenggarakannya. Menurut M.Arifin dalam Arifin ${ }^{20}$ megatakan bahwa tujuan didirikannnya pendidikan pesantren pada dasarnya terbagi pada dua, yaitu:

a.Tujuan Khusus

Yaitu mempersiapkan para santri untuk menjadi orang 'alim dalam ilmu agama yang diajarkan oleh Kyai yang bersangkutan serta mengamalkannya dalam masyarakat.

b. Tujuan Umum

${ }^{17}$ Mardiyah. Kepemimpinan Kiai dalam Memelihara Budaya Organisasi. (Yogyakarta: Aditya Media Publshing. 2012), 1.

${ }^{18}$ Nurcholish Madjid, Bilik-Bilik Pesantren, Sebuah Potret Perjalanan.(Jakarta: Paramadina, 1997). 10 .

${ }^{19}$ Zamakhsyari Dhofier, Tradisi Pesantren Studi Pandangan Hidup Kiai dan Visinya Mengenai Masa Depan Indonesia, (Jakarta: Pustaka Nasional, 2011),82

${ }^{20}$ Zainal Arifin, Konsep dan Model Pengembangan Kurikulum,(Bandung: Rosda, 2011). 248. 
Yakni membimbing santri agar menjadi manusia yang berkepribadian Islam yang sanggup dengan ilmu agamanya menjadi mubaligh Islam dalam masyarakat sekitar dan melalui ilmu dan amalnya.

Sedangkan Profesor Mastuhu dalam Nafi' dkk ${ }^{21}$ menjelaskan bahwa tujuan utama pesantren adalah untuk mencapai hikmah atau wisdom(kebijaksanaan) berdasarkan pada ajaran Islam yang dimaksudkan untuk meningkatkan pemahaman tentang arti kehidupan serta realisasi dari peranperan dan tanggung jawab sosial. Setiap santri diharapkan menjadi orang yang bijaksana dalam menyikapi kehidupan ini. Santri bisa dikatakan bijaksana manakala sudah melengkapi persyaratan menjadi seorang yang 'alim (menguasai ilmu, cendekiawan), shalih (baik, patut, lurus, berguna, serta cocok), dan nasyir al-ílm (penyebar ilmu dan ajaran agama).

3. Unsur-unsur Pondok Pesantren

Dengan demikian unsur-unsur Pondok Pesantren adalah

a.Pelaku terdiri dari: kiai, ustad, santri, dan pengurus.

b. Sarana perangkat keras: misalnya masjid, rumah kiai, rumah ustad, pondok, gedung sekolah, gedung-gedung yang lain untuk pendidikan seperti perpustakaan, aula, kantor pengurus pesantren, kantor organisasi santri, keamanan, koperasi, gedung-gedung keterampilan dan lain-lain ${ }^{22}$

4. Kurikulum Pondok Pesantren

Kurikulum pesantren senantiasa mengacu pada pengertian yang luas, sehingga bisa meliputi kegiatan-kegiatan intra-kurikuler maupun ekstrakurikuler, dan bisa melibatkan disamping aktivitas yang diperankan oleh kiai. Demikian juga kegiatan-kegiatan menjadi bobot wajib diikuti maupunsekedar anjuran termasuk liputan kurikulum. Kurikulum pesantren dalam wacana selanjutnya senantiasa mengacu kepada pengertian yang luas, sehingga bisa meliputi kegiatan-kegiatan intra-kurikuler maupun ekstrakurikuler, dan bisa melibatkan disamping aktivitas yang diperankan santri juga diperankan kiai.

\footnotetext{
${ }^{21}$ Mastuhu.Dinamika Sistem Pendidikan Pesantren. (Jakarta: INIS, 1994), 49

${ }^{22}$ Zamakhsyari Dhofier, Tradisi Pesantren Studi Pandangan Hidup Kiai dan Visinya Mengenai Masa Depan Indonesia,(Jakarta: Pustaka Nasional, 2011),79.
} 


\section{Implementasi Manajemen Kurikulum Pesantren di Pon Pes Al Urwatul Wutsqo Diwek Jombang}

Gambaran kurikulum lainnya adalah pada pembagian waktu belajar, yaitu mereka belajar keilmuan sesuai dengan kurikulum yang ada di perguruan tinggi (madrasah) pada waktu kuliah, sedangkan waktu selebihnya dengan jam pelajaran yang dapat dari pagi sampai malam untuk mengkaji keilmuan Islam khas pesantren pengaiian kitab klasik. ${ }^{23}$

Kurikulum pesantren yang setara (mu'adalah) dengan pemerintah penulis akan uraikan sebagaimana berikut:

a.Landasan Filosofi

Kurikulum Satuan Pendidikan Mu'adalah dikembangkan landasan filosofi yang berdasarkan nilai-nilai kepesanrenan untuk mengembangkan memberikan dasar bagi upaya mengembangkan kapasitas peserta didik menjadi manusia muslim Indonesia yang berkualitas yang mengenai ilmuilmu agama Islam dan mampu berkonstribusi dalam kehidupan sosial. Landasan filosofi yang dijadikan pijakan dalam mengembangkan kurikulum satuan pendidikan mu'adalah seperti berikut:

1) Pendidikan mu'adalah berakar pada tradisi pesantren dalam rangka membentuk manusia seutuhnya yang mampu menjalankan peran kekhalifahan di muka bumi dan sekaligus sebagai hamba Allah yang harus mengabdikan dirinya semata-mata kepada Allah dalam menjalankan peran tersebut.

2) Kurikulum satuan pendidikan mu'adalah dikembangkan dalam rangka dasar yang menempatkan peserta didik sebagai subjek pengetahuan. Kurikulum diarahkan untuk dapat mengembangkan kapasitas peserta didik sebagai pribadi yang bukan hanya sekedarmendapatkan pengetahuan keagamaan dari kiai dan ustadz.

b. Landasan Sosiologis

Kurikulum satuan pendidikan mu'adalab dikembangkan atas dasar pengakuan adanya praktik pendidikan yang sangat baik yang berlangsung di pondok pesantren dalam rangka mengembangkan potensi peserta didik agar menjadi manusia yang beriman dan bertakwa kepada Allah SWT, berakhlak

${ }^{23}$ Ridwan Abawihda,Kurikulum Pendidikan dan Tantangan Perubahan Global. (Jakarta: Pustaka Belajar. 2012), 117. 
mulia, berilmu, cakap, kreatif, mandiri, dan menjadi warga Negara yang demokratis serta bertanggung jawab sebagaimana termaaktub dalam tujuan pendidikan nasional.

Pengembangkan kurikulum pada satuan pendidikan mu'adalah juga didasarkan atas tradisi yng berorientasi pada penguasaan kitab kuning yang merupakan salah satu karakteristik pondok pesantren di tanah air dalam upaya mencetak kader ulama' yang mutafaqqih fid din yang bertumpu pada nilai-nilai kultural yang moderat.

c.Landasan Psikopedagogis

Kurikulum satuan pendidikan mu'adalah dikembangkan atas dasar tradisi epistimologi Islam yang meyakini bahwa ilmu tidak hanya diperoleh melalui kajian eksperimen yang dilakukan secara rasional, tetapi juga merupakan nur Allah SWT yang terpancar kedalam hati manusia yang meniscayakan adanya kesucian. Proses penyucian hati yang dilakukan melalui berbagai kegiatan ubudiyah, mujahadah, dan riyadhah untuk mendekatkan diri kepada Allah dan bukan untuk mencari kemegahan dan kedudukan.

d. Landasan Yuridis

Landasan yuridis pengembangan kurikulum pada satuan pendidikan mu'adalab adalah:

1) Undang-undang Dasar Negara Republik Indonesia Tahun 1945;

2) Undang-undang Nomor 20 Tahun 2003 Tentang Sistem Pendidikan Nasional;

3) Peraturan Pemerintah Nomor 19 Tahun 2005 Tentang Standar Nasional Pendidikan sebagaimana telah dua kali diubah terakhir dengan Peraturan Pemerintah Nomor 15 Tahun 2015 Tentang perubahan Kedua Atas Peraturan Pemerintah Nomor 19 Tahun 2005 tentang Standar Nasional Pendidikan;

4) Peraturan Pemerintah Nomor 55 Tahun 2007 Tentang Pendidikan Agama dan Pendidikan Keagamaan;

5) Peraturan Menteri Agama Republik Indonesia Nomor 13 Tahun 2014 Tentang Pendidikan Keagamaan Islam; 


\section{Implementasi Manajemen Kurikulum Pesantren di Pon Pes Al Urwatul Wutsqo Diwek Jombang}

6) Peraturan Menteri Agama Republik Indonesia Nomor 18 Tahun 2014 Tentang Satuan Pendidikan Mu'adalab pada Pondok Pesantren.

\section{Analisis}

\section{Implementasi Manajemen Kurikulum Pesantren di Pondok Pesantren al} Urwatul Wutsqo Diwek Jombang

a. Perencanaan Kurikulum Pesantren di Pondok Pesantren al Urwatul Wutsqo

Proses implementasi manajemen kurikulum di pondok pesantren al Urwatul Wutsqo maka sangat berkaitan dengan visi misi pondok pesantren agar terbentuknya masyarakat berkepribadian mulia paham al quran dan pengagung tuhan maha pencipta. Untuk mewujudkan tujuan tersebut maka perlu adanya implementasi kurikulum pesantren.

Berdasarkan observasi, wawancara dan dokumentasi yang telah dilakukan peneliti, dapat diketahui bahwa kurikulum di pondok pesantren al Urwatul Wutsqo Diwek Jombang disesuaikan dengan visi misi pondok pesantren adalah Terwujudnya masyarakat berkepribadian mulia, paham al quran, pengagung Tuhan maha pencipta melalui pendidik yang pejuang”. Sehingga kurikulum yang dibuat juga mengutamakan al quran atau kurikulum berbasis al quran.

Sesuai dengan teori bahwasanya dalam implementasi manajemen kurikulum terdapat lima prinsip yang harus diperhatikan ${ }^{24}$ (yaitu: produktivitas, demokratisasi, kooperatif, efektifitas dan efisiensi, mengarahkan visi, misi, dan tujuanyang ditetapkan dalam kurikulum, proses manajemen kurikulum harus dapat memperkuat dan mengarahkan visi, misi dan tujuan kurikulum. Tahaptahap pelaksanaan kurikulum mencakup tiga kegiatan pokok, yaitu perencanaan kurikulum, pelaksanaan kurikulum, dan evaluasi.

Penerapan kurikulum di pondok pesantren dimulai dari tahap perencanaan. Pada tahap perencanaan seluruh pihak yang terkait mulai dari stakeholder, ustadz-ustadzah melakukan musyawaroh dalam menetapkan kurikulum. Kurikulum yang dimusyawarohkan semua yang terkait struktur kurikulum, pengajaran dan waktu. Implementasi manajemen kurikulum

${ }^{24}$ Dinn. Wahyudin,Manajemen Kurikulum. (Bandung: Remaja Rosdakarya, 2014), 20-21 
pondok pesantren al Urwatul Wutsqo tidak sama dengan lembaga pada umumnya, seperti qur'an dan tafsir amaly.

Sesuai dengan teori yang dikemukakan oleh Hamalik dalam bukunya yang berjudul Manajemen Kurikulum. Beliau menyatakan bahwa pihak-pihak yang terlibat dalam perencanaan kurikulum sebagai berikut; admistrator, pelajar/siswa, warga/masyarakat, penyusun kurikulum, guru, pimpinan penyusun kurikulum. Disamping perencanaan yang merupakan tujuan pendidikan dan susunan bahan pelajaran, pemerintah pusat mengeluarkan pedoman-pedoman umum yang harus diikuti oleh sekolah untuk menyusun perencanaan yang sifatnya operasional di sekolah, pedoman-pedoman tersebut antara lain berupa: struktur program, penyusunan jadwal pelajaran, penyusunan kalender pendidikan, pembagian tugas guru, pengaturan atau penempatan siswa dalam kelas, penyusunan rencana mengajar.

Komponen-komponen perencanaan kurikulum ${ }^{25}$. Jika dikaji lebih mendalam tentang komponen-komponen apa saja yang perlu direncanakan, secara sederhana dapat dideskripsikan sebagai berikut: tujuan, isi, aktivitas belajar, sumber belajar, evaluasi.

b. Pelaksanaan Kurikulum Pesantren di Pondok Pesantren al Urwatul Wutsqo

Pelaksanaan kurikulum di pondok pesantren al Urwatul Wutsqo adalah sesuai petunjuk yang dibuat oleh stakeholder pesantren al Urwatul Wutsqo, yaitu; materi qur'any dan tafsir amaly yang diberikan kepada santri misalnya qur'any yang dilakukan pada jam setelah pembelajaran tafsir amaly atau pada jam kosong. Kerjanya sesuai dengan prinsip pengajaran qur'any $2 \times 3.2 x$ yaitu a. Menirukan, lalu b. Mengulang-ulang sendiri. 3 yaitu: bunyi:ustadz membunyikan bacaan tanpa menunjuk tulisan. Bunyikan Diulang-ulang 5 kali agar paham bunyi dan hafal. Dengan komando tirukan, ulangi, jika dikatakan. Ustadz menunjuk peraga, dengan komando: tirukan, ulangi, bunyikan dsb. Tulis: menyuruh santri mencontoh menulis pada buku tulis 5x ke bawah. Sementara itu, ustadz membina. Sedangkan tafsir amaly waktunya ba'da subuh dimulai dari jam 05.45-07.00, ba'da ashar dimulai dari jam 15.45-17.00, dan

${ }^{25}$ OemarHamalik.Dasar-dasar Pengembangan Kurikulum, (Bandung: Remaja Rosdakarya.2007), 172. 


\section{Implementasi Manajemen Kurikulum Pesantren di Pon Pes Al Urwatul Wutsqo Diwek Jombang}

ba'da isya' dimulai dari jam 19.45-20.00 yaitu mulai jam 19.45 sampai dengan 20.00. Tempat berlangsungnya pembelajaran tafsir amaly yaitu aula, ustadzah yang mengajar yaitu ustadzah yang di pertanggungjawabkan masing-masing kelas dan pelaksanaannya yaitu membaca ayat, paham arti ayat per kata, paham arti keseluruhan, tafsir amaly pada ayat al quran serta ditafsirkan dengan per kalimat pada ayat tersebut.

Hal ini sesuai dengan teori ${ }^{26}$. Beliau menjelaskan bahwa dalam penerapan kurikulum ada beberapa faktor yang mempengaruhi pelaksanaan dan perubahan kurikulum, sehingga dalam penerapan kurikulum memerlukan suatu sistem perencanaan yang meliputi komponen-komponen sebagai berikut: a) Perumusan tujuan, b) Program studi, c) Identifikasi sumber-sumber, d) Peran pihak-pihak terkait, e) Kemampuan professional, f) Unsur penunjang, g) Penjadwalan pelaksanaan, h) Sistem komunikasi, i) Sistem monitoring, j) Pencatatan dan pelaporan, k) Evaluasi proses, 1) Revisi.

Dalam pelaksanaan kurikulum tidak lepas dari metode pembelajaran. Adapun metode yang diterapkan oleh para ustadz dan ustadzah di Pondok Pesantren al Urwatul Wutsqo adalah metode diskusi dengan model peer learning (teman sejawat). Tujuan dari penerapan model peer learning ini adalah agar para santri tidak hanya bisa materi saja, tetapi para santri juga bisa menyampaikan materi yang mereka pelajari kepada teman nya atau kepada orang lain, selain itu model peer learning merupakan model pembelajaran yang terpusat pada peserta didik, dalam hal ini santri belajar dari santri lain yang memiliki status umur, harga diri tidak jauh berbeda dari dirinya sendiri. Sehingga santri tidak merasa begitu terpaksa untuk menerima ide-ide dan sikap dari gurunya yang tidak lain adalah teman sebayanya itu sendiri.

Hal ini sesui dengan teoripeer teaching merupakan kegiatan belajar yang berpusat pada peserta didik karena anggota suatu komunitas merencanakan dan memfasilitasi kesempatan belajar untuk dirinya sendiri dan orang lain. Selain itu peer learning merupakan kegiatan belajar yang berpusat pada peserta didik dalam suatu kelompok atau komunitas tertentu kemudian merencanakan dan

${ }^{26}$ OemarHamalik.Dasar-dasar Pengembangan Kurikulum, (Bandung: Remaja Rosdakarya.2007), 250 . 
memfasilitasi kesempatan belajar untuk dirinya sendiri dan orang lain. Hal ini diharapkan dapat terjadi timbal balik antara teman sebaya yang akan merencanakan dan menfasilitasi kegiatan belajar dan dapat belajar dari perencanaan dan fasilitas dari anggta kelompok lainnya.Adapun manfaat dari pembelajaran peer learning ini adalah:

a) Meningkatkan motivasi, yaitu untuk meningkatkan kualitas proses pembelajaran maupun produk pengajaran.

b) Sebagai outcome kognitif dan sosial dalam pembelajaran, yaitu meningkatkan level pendalaman atau pemikiran tingkat-tinggi (higher-order thinking), dan untuk mengembangkan keterampilan kerja sama (collaborative skills).

c) Sebagai peningkatan rasa tanggung jawab seseorang atas upaya belajar, yaitu meningkatkan penguasaan proses belajar-mengajar.

d) Meningkatkan keterampilan meta-kognitif yang memungkinkan siswa untuk lebih mencerminkan pengajaran dan pembelajaran mereka secara lebih kritis. Pada gilirannya siswa dapat lebih menghargai pengalaman belajar mereka. Proses penerapan model ini dapat dilakukan di luar lingkungan kelas dalam semua konteks pembelajaran dan pengajaran.

c. Evaluasi kurikulum di pondok pesantren al Urwatul Wutsqo

Fungsi yang terakhir adalah evaluasi. Evaluasi dilakukan secara terus menerus tapi tidak terjadwal. Evaluasi dilakukan ketika pembelajaran atau setelah pembelajaran berupa tes tulis, tes lisan dan tes praktik. Evaluasi di pondok pesantren al Urwatul Wutsqo pelaksanaan tesnya menggunakan tes formatif.

Hal ini sesuai dengan teori ${ }^{27}$ model-model evaluasi kurikulum yaitu: Evaluasi model objektif yaitu evaluasi dilakukan pada akhir pengembangan kurikulum, kegiatan ini sering disebut sumatif. Dalam hal-hal tertentu sering evaluator bekerja sebagian bagian dari tim pengembang. Informasi-informasi yang diperoleh dari hasil penilainnya digunakan untuk menyempurnakan inovasi yang sedang berjalan. Evaluasi ini sering disebut evaluasi formatif. Tes untuk mengukur prestasi belajar anak merupakan kegiatan integral dari

${ }^{27}$ Nana Syaodih dan Sukmadinata,. Pengembangan Kurikulum Teori dan Praktik.(Bandung: Remaja Rosdakarya. 2012), 185-189. 


\section{Implementasi Manajemen Kurikulum Pesantren di Pon Pes Al Urwatul Wutsqo Diwek Jombang}

kurikulum. Tiap butir tes berkenaan dengan keterampilan, unit atau tingkat tertentu dari tujuan khusus.mkemajuan siswa dimonitor oleh guru dengan memberikan tes yang mengukur tingkat penguasaan tujuan-tujuan khusus melalui pre test dan post test.

Evaluasi yang digunakan pada qur'any contoh dalam penerapan evaluasi qur'any menggunakan tes tulis, tes lisan dan tes praktik yaitu Evaluasi yang diterapkan pada materi qur'any yaitu pertama tes tulis yang berarti santri menulis tanpa mencontoh. Tes lisan berarti santri menghafal qur'any sesuai dengan kaidah qur'any yang terdapat pada buku saku maupun peraga qur'any. Setelah hafal qur'any maka santri disuruh praktik. Tes praktik berarti santri mempraktikan sesuai petunjuk pengajaran yang dihafal dengan menggunakan alat peraga qur'any. Sedangkan evaluasi pada tafsir amaly menggunakan tes lisan dan tes praktik yaitu Evaluasi pada pembelajaran tafsir amaly dilakukan tes lisan dan tes praktik. Tes lisan pada tafsir amaly yaitu santri membunyikan ayat sesuai dengan makharijul huruf atau belum. Tes praktik pada tafsir amaly yaitu santri praktik cara amaliah pada ayat tersebut.Hasil teori ${ }^{28}$ dalam pelaksnaannya,, evaluasi dapat ditempuh melalui dua cara yaitu test dan non test.

1) Teknik tes: tes tulis, tes lisan dan tes perbuatan.

2) Teknik non tes: angket, wawancara, observasi, kuensioner atau investor.

2. Faktor pendukung dan penghambat Implementasi Manajemen Kurikulum pesantren di pondok pesantren al Urwatul Wutsqo Diwek Jombang

Dalam setiap kegiatan manajemen kurikulum termasuk pelaksanaan kurikulum terjadi berbagai kendala serta ada faktor pendukung dan penghambatnya yaitu:

Faktor Pendukung, sebagai berikut:

a. Dukungan dari pondok pesantren al Urwatul Wutsqo

Karena ada dukungan dari ustadz-ustadzah pada pelaksanaan kurikulum yaitu semua ustadz-ustadzah yang mengajar dari alumni pondok pesantren al Urwatul Wutsqo, sehingga digunakan model kurikulum apapun

${ }^{28}$ Nana Syaodih dan Sukmadinata,. Pengembangan Kurikulum Teori dan Praktik, 186-188. 
dapat diikuti pada kurikulum yang dibuat langsung oleh stakeholder pondok pesantren al Urwatul Wutsqo.

b. Sarana dan prasarana yang cukup menarik yang jarang digunakan oleh lembaga lain dan mempunyai kelebihan, diantaranya:

1) Aula, adalah prasarana sebagai tempat berlangsungnya pembelajaran.

2) Alat peraga qur'any adalah sarana untuk mempermudah santri belajar.

3) Saku qur'any adalah sarana untuk mempermudah santri belajar dan menghafal qur'any.

Faktor penghambat, antara lain:

a. Faktor internal dan eksternal

Faktor internal pondok pesantren al Urwatul Wutsqo dimulai diri sendiri artina tanpa dorongan dari dirinya maka akan timbul kemalasan dalam mengikuti pembelajaran tergantung masing-masing orang, karena motivasi disebabkan santri kurang semangat. Sedangkan ekternalnya santri yang datang dari pondok pesantren al Urwatul Wutsqo kebanyakan dari luar Jawa, sehingga sulit menerima pembelajaran disini misal dari Kalimantan, Nusa Tenggara Timur sulit belajar al quran sehingga kebingungan, latar belakang pemahaman al quran masih kurang misal disuruh menghafal qur'any 3 mereka tidak mengerti”

b. Ustadz-ustadzah banyak yang masih kuliah sehingga ustadz-ustadzah kebingungan dalam mengajar, banyak ustadz-ustadzah yang banyak job dalam mengajar sehingga tidak bisa mengatur job mengajar untuk santri.

c. Ustadz-ustadzah kebingungan memetakan kemampuan santri akibatnya keberhasilan untuk belajar tidak akan selesai-selesai.

d. Umur yang sudah lanjut untuk ustadz-ustadzah sangat mempengaruhi sikap terhadap pola pengembangan pendidikan.

e. Ustadz-ustadzah yang sudah mengkader santri menjadi guru tiba-tiba boyong sehingga jarang yang mengajar. 


\section{Implementasi Manajemen Kurikulum Pesantren di Pon Pes Al Urwatul Wutsqo Diwek Jombang}

\section{Kesimpulan}

Implementasi Manajemen Kurikulum Pesantren di Pondok Pesantren al Urwatul Wutsqo Diwek Jombang: Pertama, membuat perencanaan dengan baik, yaitu melakukan musyawaroh dan pembinaan dengan stakeholder pondok pesantren dan seluruh ustadz/ustadzah meliputi perencanan yang digunakan dalam memasuki pelaksanaan, materi yang akan digunakan, waktu yang akan dilaksanakan, serta pengajar atau ustadzah di pondok pesantren al Urwatul Wutsqo agak berbeda pada umumnya. Kedua, pelaksanaan bagaimana cara pembelajaran qur'any dan tafsir amaly yang baik sangatlah penting. Kegiatan pembelajaran qur'any dan tafsir amaly dilakukan pada waktu jam kosong selain tafsir amaly. Pelaksanaan harus sesuai dengan petunjuk yang telah ditentukan oleh lembaga. Ketiga, evaluasi adalah bagian yang tak bisa ditinggalkan. Ini dilakukan ketika kegiatan pembelajaran telah selesai, maka harus ada laporan kepada ustadzah dan dipertanggungjawabkan pada stakeholder pondok pesantren al Urwatul Wutsqo tentang hasil, pendukung, dan penghambat atau kendala dalam melaksanakan kegiatan tersebut.

Faktor pendukung dalam implementasi manajemen kurikulum di pondok pesantren al Urwatul Wutsqo Diwek Jombang antara lain; faktor internal, semua ustadz-ustadzah yang mengajar dari alumni pondok pesantren al Urwatul Wutsqo, sehingga digunakan model kurikulum apapun dapat diikuti pada kurikulum yang dibuat langsung oleh stakeholder pondok pesantren al Urwatul Wutsqo, dan sarana cukup menarik yang jarang digunakan oleh lembaga lain yang mempunyai kelebihan.

Faktor penghambat implementasi kurikulum di pondok pesantren al Urwatul Wutsqo Diwek Jombang antara lain; faktor internal dan eksternal, ustadz-ustadzah banyak yang masih kuliah sehingga ustadz-ustadzah kebingungan dalam mengajar, banyak ustadz-ustadzah yang banyak job dalam mengajar sehingga tidak bisa mengatur job mengajar untuk santri, umur yang sudah lanjut untuk ustadz-ustadzah sangat mempengaruhi sikap terhadap pola pengembangan pendidikan, ustadzustadzah yang sudah mengkader santri menjadi guru tiba-tiba boyong sehingga jarang yang mengajar. 


\section{Daftar Rujukan}

Abawihda, Ridwan. 2012. Kurikulum Pendidikan dan Tantangan Perubahan Global, Jakarta: Pustaka Belajar.

Arifin, Zainal. 2011. Konsep dan Model Pengembangan Kurikulum, Bandung: Rosda.

Dakir. 2004. Perencanaan dan Pengembangan Kurikulum, Yogyakarta: Rineka Cipta.

Dhofier, Zamakhsyari. 2011. Tradisi Pesantren Studi Pandangan Hidup Kiai dan Visinya Mengenai Masa Depan Indonesia, Jakarta: Pustaka Nasional.

Hamalik, Oemar. 2007. Dasar-dasar Pengembangan Kurikulum, Bandung: Remaja Rosdakarya.

Hasan, Hamid. 2009. Evaluasi Kurikulum, Bandung: Remaja Rosdakarya.

Hidayat, Sholeh. 2013. Pengembangan Kurikulum, Bandung: Rosdakarya.

Kurniadin, Didin. 2014. Manajemen Pendidikan Konsep dan Pengelolaan Pendidikan, Yogyakarta: Arruz-media.

Madjid, Nurcholish. 1997. Bilik-Bilik Pesantren, Sebuah Potret Perjalanan, Jakarta: Paramadina.

Mardiyah. 2012. Kepemimpinan Kiai dalam Memelihara Budaya Organisasi, Yogyakarta: Aditya Media Publshing.

Mastuhu. 1994. Dinamika Sistem Pendidikan Pesantren, Jakarta: INIS.

Nasir, Ridlwan. 2005. Mencari Tipologi Format Pendidikan Ideal, Pondok Pesantren di Tengah Arus Perubahan, Yogyakarta: Pustaka pelajar.

Qomar, Mujamil. 2015. Pesantren dari Transformasi Metodologi Menuju Demokratisasi Institusi, Jakarta: Glora Aksara Pertama.

Rofiq. 2005. Pemberdayaan Pesantren, Yogyakarta: Pustaka Pesantren.

Rohinah, M. 2012. Memodernisasi NU 7 \& Pendidikan Islam, Jakarta: Grafindo Khasanah Ilmu.

Sudarsyah, Asep. dan Nurdin, Diding. 2009. Manajemen Implementasi Kurikulum dalam Tim Dosen Administrasi Pendidikan, Manajemen Pendidikan, Bandung: Alfabeta.

Sukmadinata. dan Syaodih, Nana. 2012. Pengembangan Kurikulum Teori dan Praktik, Bandung: Remaja Rosdakarya. 


\section{Implementasi Manajemen Kurikulum Pesantren}

di Pon Pes Al Urwatul Wutsqo Diwek Jombang

Tatang Amirin, M. 2011. Manajemen Pendidikan, Yogyakarta: UNY Press.

Wahyudin, Dinn. 2014. Manajemen Kurikulum, Bandung: Remaja Rosdakarya. 